\title{
3-Nitrotyrosine quantification methods: Current concepts and future challenges
}

\author{
Dulce Teixeira a, Rúben Fernandes ${ }^{\text {a, b }}$, Cristina Prudêncio ${ }^{\text {a, b }}$, Mónica Vieira a, b, * \\ a Ciências Químicas e das Biomoléculas, Centro de Investigação em Saúde e Ambiente, Escola Superior de Tecnologia da Saúde do Porto, Instituto Politécnico \\ do Porto, Portugal \\ ${ }^{\mathrm{b}}$ I3S - Instituto de Investigação e Inovação em Saúde, Universidade do Porto, Portugal
}

A B S T R A C T

Background: Measurement of 3-nitrotyrosine (3-NT) in biological samples can be used as a biomarker of nitrosative stress, since it is very stable and suitable for analysis. Increased 3-NT levels in biological samples have been associated with several physiological and pathological conditions. Different methods have been described for the detection and quantification of this molecule, such as (i) immunological methods; (ii) liquid chromatography, namely high-pressure liquid chromatography (HPLC)-based methods that use ultraviolet-visible (UV/VIS) absorption, electrochemical (ECD) and diode array (DAD) detection, liquid chromatography-mass spectrometry (LC-MS) and liquid chromatography-tandem mass spectrometry (LC-MS/MS); (iii) gas chromatography, such as gas chromatography-mass spectrometry (GC-MS) and gas chromatography-tandem mass spectrometry (GC-MS/MS).

Methods: A literature review on nitrosative stress, protein nitration, as well as 3-NT quantification methods was carried out.

Results: This review covers the different methods for analysis of 3-NT that have been developed during the last years as well as the latest advances in this field. Overall, all methods present positive and negative aspects, although it is clear that chromatography-based methods present good sensitivity and specificity. Regarding this, GC-based methods exhibit the highest sensibility in the quantification of 3-NT, although it requires a prior time consuming derivatization step. Conversely, HPLC does not require such derivatization step, despite being not as accurate as GC.

Conclusion: It becomes clear that all the methods described during this literature review, although accurate for 3-NT quantification, need to be improved regarding both sensitivity and specificity. Moreover, optimization of the protocols that have been described is clearly needed. 


\section{Biological markers of oxidative stress}

Oxidative stress is defined as an imbalance of antioxidants and pro-oxidants in favour of the latter, potentially leading to damage $[5,6]$. On the other hand, Jones [6] defines oxidative stress as a disruption of redox signalling and/or control of molecular damage. The reactive oxygen species (ROS) and reactive-nitrogen species (RNS) have function in redox signalling and are produced as byproducts of normal metabolic process in all aerobic organisms, at very low concentrations in cells [6,7]. Increased oxidative/nitrosative stress is characterized by inadequate cellular antioxidant defences to efficiently inactivate the overproduced ROS and RNS. A major consequence of oxidative/nitrosative stress is the damage of nucleic acid bases, proteins, lipids (including phospholipids) and carbohydrates $[7,8]$. This damage can compromise cell health and viability, as well as induce a variety of cellular responses like cell death by necrosis or apoptosis [8].

The molecules modified by interactions with ROS (including RNS) in the microenvironment, and those changed in response to increased redox stress are considered biomarkers of oxidative stress [2]. Fig. 1 represents a schematization of biomarkers of oxidative stress, which can be classified as molecules that are modified by interactions with ROS in the microenvironment, and molecules of the antioxidant system that change in response to increased redox stress.

A very promising approach for the assessment of oxidative stress is the detection of nitrated tyrosine (Tyr) residues in proteins [9].

\section{Nitrotyrosine in physiological conditions}

Tyr (4-hydroxyphenylalanine) is a non-essential amino acid and an element of the aromatic amino acids group. Most proteins found in nature contain Tyr residues in their composition, with an average abundance of about $3-4 \mathrm{~mol} \%[10,11]$. Tyr is moderately hydrophilic, which is explained by its hydrophobic aromatic benzene ring carrying a hydroxyl group $[12,13]$. As a result, Tyr is frequently surface-exposed in proteins allowing further modification, namely nitration. The nitration of Tyr residues in proteins is associated with nitrosative stress, resulting in the formation of 3-nitrotyrosine (3NT) or other Tyr-nitrated proteins residues [10,14].

When RNS reacts with L-tyrosine and protein-associated Tyr, free 3-nitro-L-tyrosine and protein-associated 3-nitro-L-tyrosine are formed (Fig. 2) [1]. 3-NT [(2-amino-3-(4-hydroxy-3nitrophenyl) propanoic acid)] is the result of a post-translational modification in proteins carried by RNS, such as nitric oxide (NO), derived oxidants (e.g., peroxynitrite $\left(\mathrm{ONOO}^{-}\right)$and peroxynitrous acid $(\mathrm{ONOOH})$ ) and nitrogen dioxide radicals $\left({ }^{\circ} \mathrm{NO}_{2}\right)$. It is formed after the substitution of a hydrogen by a nitro group $\left(\mathrm{NO}_{2}\right)$ in the ortho position of the phenolic ring of the Tyr residues $[10,11,13,14]$.

The protein tyrosine nitration (PTN) is a stable posttranslational modification process and does not happen randomly. The abundance of protein or Tyr residues cannot predict whether they will be the target of PTN. Furthermore, not all Tyr residues in a protein are available for nitration, which may depend on their accessibility to the solvent $[10,15]$. For instance, although the human serum albumin (HSA), a protein most abundantly found in plasma, contains 18 Tyr residues, an in vitro study showed that only two of its Tyr residues are predominantly susceptible to nitration $[14,16]$.

The wide range of chemical and structural modifications of proteins, such as modifications affecting signal transduction pathways and cellular processes, are responsible for high levels of RNS and antioxidant enzymatic systems $[17,18]$.

\section{Metabolism of nitric oxide and its role in 3-nitrotyrosine biosynthesis}

The major pathway for NO metabolism is the stepwise oxidation to nitrite and nitrate [3]. In biological fluids or buffers, NO systems are almost completely oxidized to nitrite $\left(\mathrm{NO}_{2}^{-}\right)$, a biologically inert metabolite of NO oxidation [19].

The oxidation of NO by molecular oxygen $\left(\mathrm{O}_{2}\right)$, physically dissolved in biological systems, originates $\mathrm{NO}_{2}$ (nitrogen dioxide), $\mathrm{N}_{2} \mathrm{O}_{3}$ (dinitrogen trioxide) and $\mathrm{NO}_{2}^{-}$(reactions 1,2 and 3). $\mathrm{N}_{2} \mathrm{O}_{3}$ is characterized as a potent nitrosating agent, since it gives rise to the formation of the nitrosonium ion $\left(\mathrm{NO}^{+}\right)$. On the other hand, $\mathrm{NO}$ and $\mathrm{NO}_{2}^{-}$are rapidly oxidized to nitrate $\left(\mathrm{NO}_{3}^{-}\right)$in blood $[3,14]$.

$$
\begin{aligned}
& 2 \mathrm{NO}+\mathrm{O}_{2} \rightarrow 2 \mathrm{NO}_{2} \\
& 2 \mathrm{NO}+2 \mathrm{NO}_{2} \rightarrow 2 \mathrm{~N}_{2} \mathrm{O}_{3} \\
& 2 \mathrm{~N}_{2} \mathrm{O}_{3}+2 \mathrm{H}_{2} \mathrm{O} \rightarrow 4 \mathrm{NO}_{2}^{-}+4 \mathrm{H}^{+}
\end{aligned}
$$

In erythrocytes, $\mathrm{NO}$ directly and rapidly reacts with $\mathrm{O}_{2}$ bound to haemoglobin (i.e. oxyhemoglobin $\left(\mathrm{Hb}\left[\mathrm{Fe}^{2+}\right] \mathrm{O}_{2}\right)$ ), to form the chemically quite inert anion $\mathrm{NO}_{3}^{-}$(reaction 4).

$\mathrm{Hb}\left[\mathrm{Fe}^{2+}\right] \mathrm{O}_{2}+\mathrm{NO} \rightarrow \mathrm{Hb}\left[\mathrm{Fe}^{3+}\right]+\mathrm{NO}_{3}^{-}$

Other proposed mechanism for $\mathrm{NO}_{3}^{-}$formation is via oxidation of $\mathrm{NO}_{2}^{-}$(derived from $\mathrm{NO}$ autoxidation - reaction 3 ) by certain oxyhemoproteins $\left(\mathrm{Hb}\left[\mathrm{Fe}^{2+}\right] \mathrm{O}_{2}\right)$, such as oxyhemoglobin or oxymyoglobin (reactions 5 and 6) [3].

$$
2 \mathrm{Hb}\left[\mathrm{Fe}^{2+}\right] \mathrm{O}_{2}+3 \mathrm{NO}_{2}^{-}+2 \mathrm{H}^{+} \rightarrow 2 \mathrm{Hb}\left[\mathrm{Fe}^{3+}\right]+3 \mathrm{NO}_{3}^{-}+\mathrm{H}_{2} \mathrm{O}
$$

$$
\begin{aligned}
& 4 \mathrm{Hb}\left[\mathrm{Fe}^{2+}\right] \mathrm{O}_{2}+4 \mathrm{NO}_{2}^{-}+4 \mathrm{H}^{+} \rightarrow 4 \mathrm{Hb}\left[\mathrm{Fe}^{3+}\right]+4 \mathrm{NO}_{3}^{-}+\mathrm{O}_{2} \\
& \quad+2 \mathrm{H}_{2} \mathrm{O}
\end{aligned}
$$

Concerning free radical superoxide $\left(\mathrm{O}_{2}^{-}\right)$, this may promptly interact with $\mathrm{NO}$ to produce the peroxynitrite anion $\left(\mathrm{ONOO}^{-}\right)$(reaction 7) [20,21].

$\mathrm{NO}+\mathrm{O}_{2}^{--} \rightarrow \mathrm{ONOO}^{-}$ 


\section{Sources of reactive oxygen species}

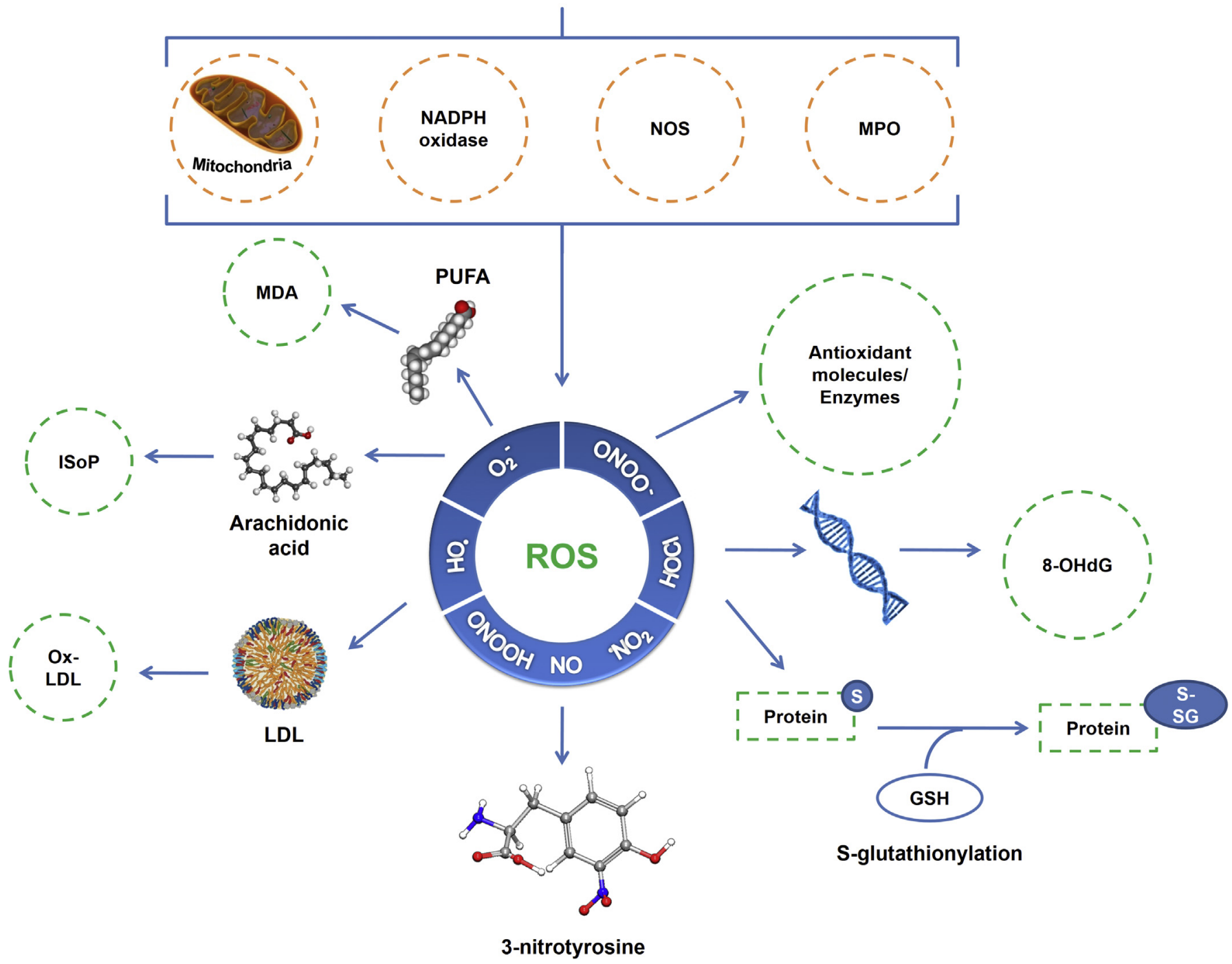

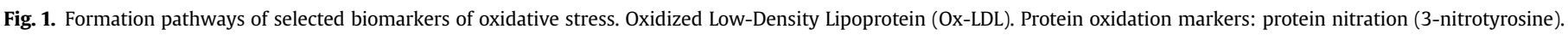

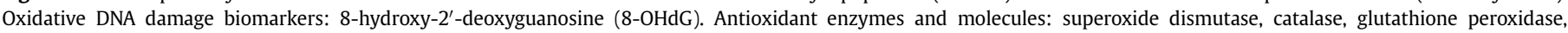

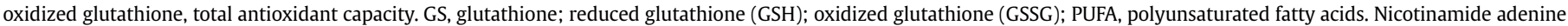
dinucleotide phosphate (NADPH), nitric oxide synthase (NOS), mieloperoxidase (MPO). Adapted from Ho et al. [2] and Shah et al. [4].

Peroxynitrite is the extremely reactive conjugate base of peroxynitrous acid $(\mathrm{ONOOH})$ (reaction 8$)[3,14]$.

$$
4 \mathrm{ONOO}^{-}+4 \mathrm{H}^{+} \leftrightarrow 4 \mathrm{ONOOH} \rightarrow 2 \mathrm{NO}_{3}^{-}+2 \mathrm{NO}_{2}^{-}+\mathrm{O}_{2}+4 \mathrm{H}^{+}
$$

In biological systems, $\mathrm{ONOO}^{-} / \mathrm{ONOOH}$ system is a very strong oxidant and a potent nitrating agent, thus it has been implicated as a culprit in many diseases [22]. Peroxynitrite promotes nitration and hydroxylation in different bioorganic molecules, including proteins, lipids, thiols, sulfhydryl groups, DNA bases, and preferentially nitrates Tyr residues of protein or non-protein origins $[23,24]$. Peroxynitrite reacts whit $\mathrm{CO}_{2}$ to yield a nitrosoperoxycarbonate anion $\left(\mathrm{ONOOCO}_{2}^{-}\right)$that undergoes a fast homolysis to $\mathrm{NO}_{2}$ and carbonate radicals $\left(\mathrm{CO}_{3}^{-}\right)$(reaction 9$)$ [18,23,25].

$\mathrm{ONOO}^{-}+\mathrm{CO}_{2} \rightarrow \mathrm{ONOOCO}_{2}^{-} \rightarrow{ }^{\bullet} \mathrm{NO}_{2}+\mathrm{CO}_{3}^{\bullet-}$

The in vivo production of $\mathrm{ONOO}^{-}$leads to the nitration of Tyr residues in proteins, forming 3-NT, although it does not directly react with Tyr. Instead, it forms secondary radicals, such as $\mathrm{CO}_{3}^{--}$,
- $\mathrm{NO}_{2}$ and oxo-metal complexes, which are indeed responsible for protein Tyr oxidation and nitration. The mechanism of Tyr nitration in biological systems is a two-step process (reactions 10 and 11) [23].

$\mathrm{TyrH}+\mathrm{CO}_{3}^{\bullet-} \rightarrow \mathrm{Tyr}^{\bullet}+\mathrm{HCO}_{3}^{-}$

$\mathrm{Tyr}^{\bullet}+{ }^{\bullet} \mathrm{NO}_{2} \rightarrow \mathrm{Tyr}-\mathrm{NO}_{2}$

Moreover, 3-NT may be generated through multiple pathways (Fig. 3). Tyr can be nitrated by peroxidase (or heme/hemoprotein) through the in vivo hydrogen peroxide-dependent oxidation of nitrite to form $\mathrm{NO}_{2}$ (reactions 12-14) [3,18,26].

$\mathrm{H}_{2} \mathrm{O}_{2}+$ peroxidase(heme) $\rightarrow$ oxidant(porphyrin radical)

Oxidant $+\mathrm{NO}^{2-} \rightarrow \cdot \mathrm{NO}_{2}$ 
L-tyrosine<smiles>NC(Cc1ccc(O)cc1)C(=O)O</smiles><smiles>NC(=O)Cc1ccc(O)c([N+](=O)[O-])c1</smiles>

Protein-associated

L-tyrosine<smiles>CCNC(Cc1ccc(O)cc1)C(=O)O</smiles>

$\mathrm{OH}$

Protein-associated 3-nitro-L-tyrosine

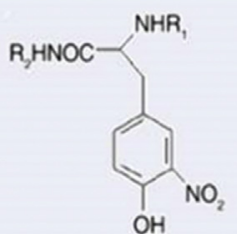

Fig. 2. Nitration of L-tyrosine to 3-nitro-L-tyrosine (Adapted from Tsikas and Caidahl [1]).

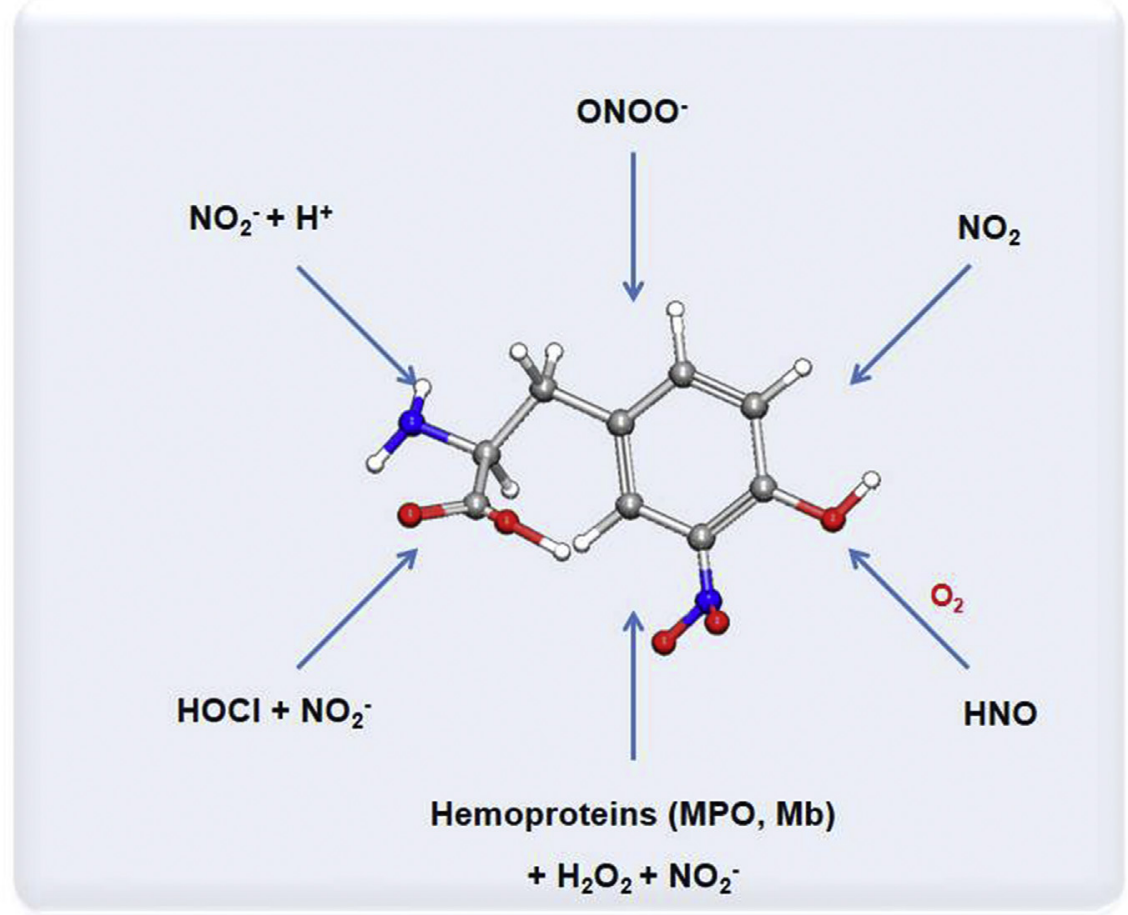

Fig. 3. Multiple pathways for the formation of 3-nitrotyrosine (Adapted from Bryan and Grisham [3]).

$2^{\bullet} \mathrm{NO}_{2}+\operatorname{Try} \rightarrow 3-\mathrm{NT}$

\section{Association between 3-nitrotyrosine and disease}

Several physiological and pathological conditions have been associated with increased nitration of proteins [15,21]. Table 1 shows the 3-NT concentration range usually found in both healthy and pathological states, as determined by different 
Table 1

3-NT concentration ranges found in different biological samples from both healthy and pathological states, as determined by different methodologies.

\begin{tabular}{|c|c|c|c|c|}
\hline Reference & Sample (mean age \pm years) & Biological sample & Method & Concentration 3-NT \\
\hline $\begin{array}{l}\text { Söderling et al. } \\
\text { [54] }\end{array}$ & 12 Healthy non-smoking volunteers $(43 \pm 9)$ & Plasma & GC/NCI-MS/MS & $0.74 \pm 0.31 \mathrm{nM}^{\mathrm{a}}$ \\
\hline \multirow{4}{*}{ Tsikas et al. } & 10 Healthy volunteers $(51 \pm 10)$ & Plasma & GC tandem MS & $1.149 \pm 0.73 \mathrm{nM}^{\mathrm{a}}$ \\
\hline & 6 Healthy volunteers $(25 \pm 3)$ & Plasma & GC tandem MS & $2.677 \pm 1.540 \mathrm{nM}^{\mathrm{a}}$ \\
\hline & 10 Healthy volunteers $(51 \pm 10)$ & Plasma & GC-MS & $4.46 \pm 4.49 \mathrm{nM}^{\mathrm{a}}$ \\
\hline & 6 Healthy volunteers $(25 \pm 3)$ & Plasma & GC-MS & $5.447 \pm 2.783 \mathrm{nM}^{\mathrm{a}}$ \\
\hline \multirow{2}{*}{$\begin{array}{l}\text { Zhang et al. } \\
\text { [56] }\end{array}$} & 20 Healthy non-smoking volunteers (41.2) & Plasma & LC-MS/MS & $4.54 \pm 2.75 \mathrm{nM}^{\mathrm{a}}$ \\
\hline & 18 Healthy smokers $(42.0)$ & Plasma & LC-MS/MS & $17.42 \pm 11.6 \mathrm{nM}^{\mathrm{a}}$ \\
\hline $\begin{array}{l}\text { Radabaugh } \\
\text { et al. [57] }\end{array}$ & 40 Healthy volunteers & Plasma & LC-MS/MS & $\begin{array}{l}224-962 \mathrm{pg} / \mathrm{mL}(0.99 \\
-4.2 \mathrm{nM})^{\mathrm{b}}\end{array}$ \\
\hline \multirow[t]{2}{*}{$\begin{array}{l}\text { Misko et al. } \\
\text { [39] }\end{array}$} & 143 Healthy volunteers & Plasma & $\begin{array}{l}\text { Immunoaffinity two- } \\
\text { dimensional LC-MS/MS }\end{array}$ & $536.4 \mathrm{pg} / \mathrm{mL}(2.49 \mathrm{nM})^{\mathrm{b}}$ \\
\hline & 174 Osteoarthritis patients & Plasma & $\begin{array}{l}\text { Immunoaffinity two- } \\
\text { dimensional LC-MS/MS }\end{array}$ & $704.1 \mathrm{pg} / \mathrm{mL}(3.11 \mathrm{nM})^{\mathrm{b}}$ \\
\hline \multirow[t]{3}{*}{$\begin{array}{l}\text { Pourfarzam } \\
\text { et al. [32] }\end{array}$} & 50 Patients with no history of cardiac diseases $(58.9 \pm 10.3)$ & Plasma & $\begin{array}{l}\text { HPLC-fluorescence detector } \\
470 \mathrm{~nm}\end{array}$ & $4.4 \pm 1.8 \mathrm{nM}^{\mathrm{a}}$ \\
\hline & 50 Stable CAD patients $(61.2 \pm 11.23)$ & Plasma & $\begin{array}{l}\text { HPLC-fluorescence detector } \\
470 \mathrm{~nm}\end{array}$ & $12.8 \pm 3.9 \mathrm{nM}^{\mathrm{a}}$ \\
\hline & 50 Unstable CAD patients $(59.9 \pm 10.45)$ & Plasma & $\begin{array}{l}\text { HPLC-fluorescence detector } \\
470 \mathrm{~nm}\end{array}$ & $14.8 \pm 4.8 \mathrm{nM}^{\mathrm{a}}$ \\
\hline Sun et al. [26] & 70 Healthy Chinese volunteers & Plasma & Sandwich ELISA & $7.9 \pm 7 \mathrm{nmol} / \mathrm{L}^{\mathrm{b}}$ \\
\hline $\begin{array}{l}\text { Radabaugh } \\
\text { et al. [57] }\end{array}$ & 131 Healthy volunteers & Serum & LC-MS/MS & $\begin{array}{l}179-1540 \mathrm{pg} / \mathrm{mL}(0.79 \\
-6.8 \mathrm{nM})^{\mathrm{b}}\end{array}$ \\
\hline \multirow{2}{*}{ Khan et al. } & 25 Non-smoking healthy female volunteers (age 24-50) & Serum & Sandwich ELISA & $1.1 \pm 0.81 \mu \mathrm{M}^{\mathrm{b}}$ \\
\hline & 24 Systemic lupus erythematosus patients (age $18-50$ ) & Serum & Sandwich ELISA & $96.52 \pm 21.12 \mu \mathrm{M}^{\mathrm{b}}$ \\
\hline $\begin{array}{l}\text { Tsikas et al. } \\
\quad[59]\end{array}$ & 10 Healthy volunteers $(36.5 \pm 7.2)$ & Urine & GC-tandem MS & $8.4 \pm 10.4 \mathrm{nM}$ \\
\hline $\begin{array}{l}\text { Radabaugh } \\
\text { et al. [57] }\end{array}$ & 8 Healthy volunteers & Urine & LC-MS/MS & $\begin{array}{l}63.5-751 \mathrm{pg} / \mathrm{mL}(0.28 \\
-3.32 \mathrm{nM})^{\mathrm{b}}\end{array}$ \\
\hline \multirow[t]{3}{*}{$\begin{array}{l}\text { Ryberg et al. } \\
\text { [60] }\end{array}$} & $\begin{array}{l}19 \text { Patients without history or symptoms/signs of psychiatric, neurological, } \\
\text { malignant or systemic disorders }\end{array}$ & $\begin{array}{l}\text { Cerebrospinal } \\
\text { fluid }\end{array}$ & GC/NCI-MS/MS & $0.35 \pm 0.019 \mathrm{nM}^{\mathrm{a}}$ \\
\hline & 17 Alzheimer's disease patients & $\begin{array}{l}\text { Cerebrospinal } \\
\text { fluid }\end{array}$ & GC/NCI-MS/MS & $0.44 \pm 0.031 \mathrm{nM}^{\mathrm{a}}$ \\
\hline & 14 Amyotrophic lateral sclerosis patients & $\begin{array}{l}\text { Cerebrospinal } \\
\text { fluid }\end{array}$ & GC/NCI-MS/MS & $0.38 \pm 0.034 \mathrm{nM}^{\mathrm{a}}$ \\
\hline $\begin{array}{l}\text { Radabaugh } \\
\text { et al. [57] }\end{array}$ & 35 Healthy volunteers & $\begin{array}{l}\text { Cerebrospinal } \\
\text { fluid }\end{array}$ & LC-MS/MS & $\begin{array}{l}335-5730 \mathrm{pg} / \mathrm{mL}(1.48 \\
-25.33 \mathrm{nM})^{\mathrm{b}}\end{array}$ \\
\hline $\begin{array}{l}\text { Seven et al. } \\
\quad[61]\end{array}$ & 15 Volunteers with normal pressure hydrocephalia & $\begin{array}{l}\text { Cerebrospinal } \\
\text { fluid }\end{array}$ & ELISA based on the sandwich & $573.54 \pm 142.86 \mathrm{nM}$ \\
\hline $\begin{array}{l}\text { Seven et al. } \\
\text { [61] }\end{array}$ & $\begin{array}{l}20 \text { Relapsing remitting multiple sclerosis patients before methyl } \\
\text { prednisolone therapy }\end{array}$ & $\begin{array}{l}\text { Cerebrospinal } \\
\text { fluid }\end{array}$ & ELISA based on the sandwich & $927.89 \pm 244.84 \mathrm{nM}$ \\
\hline \multirow[t]{2}{*}{$\begin{array}{l}\text { Lärstad et al. } \\
\text { [62] }\end{array}$} & 10 Healthy subjects $(46 \pm 2.6)$ & $\begin{array}{l}\text { Exhaled breath } \\
\text { condensate }\end{array}$ & GC/NICI/tandem MS & $31 \mathrm{pM}^{\mathrm{a}}$ \\
\hline & 8 Asthma patients $(49 \pm 5.1)$ & $\begin{array}{l}\text { Exhaled breath } \\
\text { condensate }\end{array}$ & GC/NICI/tandem MS & $31 \mathrm{pM}^{\mathrm{a}}$ \\
\hline $\begin{array}{l}\text { Radabaugh } \\
\quad \text { et al. [57] }\end{array}$ & 40 Healthy volunteers & Synovial fluid & LC-MS/MS & $\begin{array}{l}54.4-822 \mathrm{pg} / \mathrm{mL}(0.24 \\
-3.63 \mathrm{nM})^{\mathrm{b}}\end{array}$ \\
\hline \multirow{2}{*}{$\begin{array}{l}\text { Ueshima et al. } \\
\text { [63] }\end{array}$} & 5 Chronic obstructive pulmonary disease patients $(71.6 \pm 2.4)$ & Sputum & HPLC-ECD & $0.55 \pm 0.15 \mathrm{pmol} / \mathrm{mL}^{\mathrm{b}}$ \\
\hline & 5 Chronic obstructive pulmonary disease patients $(71.6 \pm 2.4)$ & Saliva & HPLC-ECD & $0.02 \pm 0.01 \mathrm{pmol} / \mathrm{mL}^{\mathrm{b}}$ \\
\hline
\end{tabular}

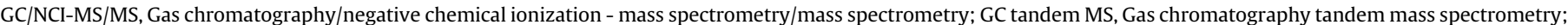

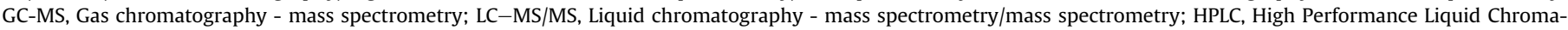
tography; ELISA, Enzyme-Linked Immunosorbent Assay; ECD, electrochemical.

a Free 3-NT.

b Total 3-NT.

methods (discussed in detail in the following sections) and biological samples. According to Table 1, 3-NT levels in pathological conditions are slightly higher in comparison with basal levels in healthy individuals. This observation is in fact valid for several biological specimens, regardless the quantification method used.

Among the pathological conditions, there is a wide range of cardiovascular diseases, such as myocardial inflammation, heart failure and arteriosclerosis [5,27-30]. For instance, Shishehbor et al. [31] and Poufarzam et al. [32] demonstrated that 3-NT plasma levels are elevated in coronary artery disease (CAD) patients. Regarding atherosclerosis, it was found that atherosclerotic arteries have higher 3-NT levels than non-atherosclerotic blood vessels [33]. Furthermore, there is also evidence of an accumulation of 3NT during atherogenesis [34].

In addition, diseases associated with immunological reactions appear to be connected at a very high degree with the increased formation of Tyr-nitrated proteins, such as asthma [35], systemic sclerosis [36], renal complications [4], inflammatory bowel disease [37], septic shock [38], rheumatoid arthritis and joint injury [39,40]. In relation to asthma, 3-NT expression was found to be increased in several asthmatic epithelial cells and essentially in asthmatic children [35,41]. Concerning systemic sclerosis, Shimizu et al. [36] suggested that serum 3-NT levels are significantly increased in systemic sclerosis patients compared to healthy controls. Regarding inflammatory bowel diseases, such as ulcerative colitis, the 3-NT expression is substantially increased in the inflamed colonic mucosa [37].

Furthermore, some neurological diseases and psychiatric disorders are also associated with an increased level of nitrated proteins. For example, Parakh et al. [42] reported that nitrated proteins 
and high levels of 3-NT have been detected in cases of amyotrophic lateral sclerosis. Conversely, Mendonça et al. [43] demonstrated that 3-NT was expressed in both amyotrophic lateral sclerosis and control samples, with no significant difference between them. Moreover, Dietrich-Muszalska et al. [44] considered that the amount of 3-NT in plasma proteins may be important indicators of in vivo protein damage in schizophrenia. Besides, high levels of 3NT have also been associated with other pathological conditions, such as Alzheimer's disease [45], Parkinson's disease [46], autism [47] and myalgic encephalomyelitis/chronic fatigue syndrome [48].

Other diseases are associated with increased protein nitration. Shu et al. [49] demonstrated that 3-NT levels in plasma samples from patients with classical Fabry disease were about six-fold higher compared with age- and gender-matched controls. The 3NT levels are also significantly increased in diabetic patients [5,50], especially in patients with diabetic nephropathy [51] or diabetic patients with microvascular complications [52]. Regarding Chagas disease, Dhiman et al. [53] considered that 3-NT-modified proteins is an important phase in the pathophysiology of such disease, and might be useful biomarkers of disease as well. Moreover, Shah et al. [4] demonstrated that 3-NT levels were increased in plasma and serum of patients with systemic lupus erythematosus.

\section{Quantification of 3-nitrotyrosine in biological samples}

Since 3-NT was suggested as a biomarker of nitrosative stress, a substantial effort has been made to develop analytical methods that can be applied to biological samples [64]. Accurate quantification of substances present in biological samples at very low concentrations is, indeed, a complex task, and the particular case of 3-NT requires special concerns [1].

3-NT has been detected in several biological tissues and fluids including plasma, serum, urine, cerebrospinal fluid, synovial fluid, tissue samples and other biological samples [57]. Recently, Mergola et al. [65] developed for the first time the synthesis of a highly selective molecularly imprinted polymer (MIP) used as solid-phase extraction (SPE) sorbent for pre-concentration of 3-NT and the selective clean-up from biological sample. The results obtained suggest that this polymer can be used as an active site in a sensor so that the analyte can be directly identified in the urine of patients, where it is normally present at very low concentrations.

A common approach for 3-NT quantification is the prior cleavage of peptide bonds in order to release the free amino acids from proteins in fluids or tissues. This cleavage may be achieved by acid hydrolysis or enzymatic digestion [14,57,66]. Delatour et al. [66] compared both methods in terms of the reliability of the 3-NT measurement, providing evidence that acid hydrolysis leads to more reliable results. However, Radabaugh, et al. [57] pointed out that a prior acid hydrolysis step is more prone to artifact formation in comparison with enzymatic digestion.

Regarding quantification of 3-NT, the first approaches used different immunological methods. In fact, a large part of studies on quantification of 3-NT in biological samples has been performed using antibody-based methods, namely immunohistochemistry and western blot [13].

\subsection{Immunochemical methods}

\subsubsection{Enzyme-linked immunosorbent assay}

ELISA (enzyme-linked immunosorbent assay) is based on the basic immunology concept of the binding properties of an antibody to its specific antigen. From a general point of view, this method employs enzyme-labelled antigens and antibodies to detect a wide variety of compounds. The antigen-antibody complex is further bound by a secondary enzyme-coupled antibody, followed by the addition of a chromogenic substrate which yields a visible colour change or fluorescence, allowing the quantification of the compound [67]. One of the main advantages of ELISA technology is that it allows the simultaneous determination of standards and samples. Moreover, it does not require complex sample preparation steps [67].

Regarding 3-NT quantification, there is a wide variety of ELISAbased methods for this purpose, namely indirect, competitive, sandwich-ELISA and ELISA microarrays [68,69]. Table 2 lists some ELISA assays for the analysis of 3-NT in different biological specimens.

One of the first ELISA methods for the analysis of nitrated proteins in biological fluids was based upon a competitive model [72]. More recently, Safinowski et al. [9] performed a comparison of the performance of different commercially available immunoassays for 3-NT analysis, and concluded that all of them did not provide reliable results. They also concluded that the sandwich-based ELISA assay exhibited the worst performance, probably due to the low concentration levels of 3-NT in almost all investigated samples. ELISA requires at least two 3-NT residues for the capture and detection antibody and, in this sense, the sandwich ELISA measures only protein associated-3-NT $[9,26,69]$. Actually, the poor performances exhibited by different ELISA can be due to different reasons: (i) the antibodies may reveal some nonspecific binding; (ii) 3NT may not be totally accessible to the antibody in some protein sites; and (iii) monoclonal and polyclonal antibodies used by these methods may exhibit cross-reactivity with other compounds present in biological samples [73].

Regarding microarray-ELISA assays, one of their main advantages is that they use various physically separated capture antibodies (in isolated spots), allowing an efficient way for measuring low levels of the analyte [68].

\subsection{Chromatographic methods}

Chromatography is a powerful analytical technique, and is widely available in different laboratory settings nowadays [74]. This technique is generally composed by two primary components: mobile phase and stationary phase [75].

Table 3 shows chromatography classifications according to the mobile and stationary phases used.

\subsubsection{Liquid chromatography methods using ultraviolet,} fluorescence and electrochemical detection

Liquid chromatography (LC) is one of the most extensively used methods for the determination of 3-NT (Table 4). Several different detectors have been employed, such as ultra-violet (UV), electrochemical (ECD), diode-array (DAD) and mass spectrometry (MS) [14].

HPLC (High Performance Liquid Chromatography) is a chromatographic technique that can separate a mixture of compounds, and is used in biochemistry and analytical chemistry to separate, identify, quantify and purify the active compounds of a mixture [75]. The principle behind this technique relies on the injection of the sample into a column that holds packing material (stationary phase), with further pumping of the mobile phase(s) through the column, at high pressure, and the detection through the retention times exhibited by the molecules [76].

HPLC is the standard technique for analysing amino acids, being the technique used by most laboratories [13]. One of the first chromatographic methods for quantifying 3-NT uses isocratic reversed phase HPLC and UV absorbance detection at $274 \mathrm{~nm}$, as first reported by Kaur and Halliwell [77]. This HPLC-based method uses column with $\mathrm{C}-18$, eluent $\left(500 \mathrm{mM} \mathrm{KH_{2 }} \mathrm{PO}_{4}-\mathrm{F}_{3} \mathrm{PO}_{4}\right.$ with $10 \%$ methanol $(\mathrm{v} / \mathrm{v}))$, an acidic mobile phase $(\mathrm{pH} 3.01)$, and with a 
Table 2

ELISA assays for the analysis of 3-NT in different biological specimens.

\begin{tabular}{|c|c|c|c|}
\hline Compound & Biological specimen & ELISA type & Sensitivity/Detection range/Standard curve/LOD/LOQ for 3-NT \\
\hline 3-NT [70] & Bronchoalveolar lavage & Sandwich ELISA & $2.0 \mathrm{nmol} / \mathrm{L}$ (Sensitivity) \\
\hline 3-NT [50] & Plasma & Sandwich ELISA & N.S. \\
\hline 3-NT [9] & Plasma & Solid phase ELISA & 3.12-200 nM (Detection range) \\
\hline 3-NT-containing proteins [71] & Plasma & Competitive ELISA & 10 to $500 \mathrm{nM}$ (Standard curve) \\
\hline 3-NT-modifed proteins [72] & Plasma & Competitive ELISA & $10 \mu \mathrm{M}-10 \mathrm{mM}$ (Standard curve) \\
\hline 3-NT [26] & Plasma and serum & Sandwich ELISA & $1.8 \mathrm{nmol} / \mathrm{L}$ (Sensitivity) \\
\hline Protein bound 3-NT [69] & Plasma and serum & Indirect ELISA & $\begin{array}{l}1.82 \pm 0.56 \mathrm{pmol} / \mathrm{mg} \text { protein (LOD) } \\
4.29 \pm 1.56 \mathrm{pmol} / \mathrm{mg} \text { protein (LOQ) }\end{array}$ \\
\hline 3-NT [9] & Plasma and serum & Competitive luminescence assay (CLIA) & $1.68 \mathrm{nM}-101 \mu \mathrm{M}$ (Detection range) \\
\hline 3-NT [68] & Plasma and sputum & ELISA microarray & N.S. \\
\hline 3-NT [36] & Serum & Sandwich ELISA & N.S. \\
\hline Protein bound 3-NT [58] & Serum & Sandwich ELISA & $2 \mathrm{nM}(\mathrm{LOD})$ \\
\hline
\end{tabular}

LOD, limit of detection; LOQ limit of quantification; N.S.,not stated.

Table 3

Chromatographic techniques used based on samples characteristics.

\begin{tabular}{|c|c|c|c|}
\hline Chromatographic technique & Mobile phase & Stationary phase & Sample \\
\hline Gas chromatography & Gas & Solid/liquid & $\begin{array}{l}\text { Gaseous sample (ordinary temperatures) } \\
\text { Samples that vaporise (when heated) }\end{array}$ \\
\hline Liquid chromatography & Liquid & Solid/liquid & $\begin{array}{l}\text { Liquid samples } \\
\text { Solid samples (solvent-soluble) }\end{array}$ \\
\hline
\end{tabular}

detection limit of $0.2 \mu \mathrm{M}$ [77]. Variants of this method have been used in several studies to determine 3-NT. Hitomi et al. [78] performed an optimization of 3-NT separation process, showing that it depends on the mobile phase used. Moreover, the retention time depends on two factors, (i) the pH of the mobile phase, and (ii) the concentration of acetonitrile. The retention time was prolonged by a powerfully acidic mobile phase.

HPLC-UV detector. The HPLC-UV allows the detection of 3-NT as free amino acid, and associated with peptides and proteins as well [79]. Tyr and 3-NT have a maximum absorbance at $280 \mathrm{~nm}$ in solution at $\mathrm{pH}$ 3.5. Additionally, 3-NT has a second absorbance at $357 \mathrm{~nm}$. However, this second wavelength is more selective and, therefore, more suitable for detection purposes. In basic solutions (pH 9.5), 3-NT has a maximum absorbance at $430 \mathrm{~nm}[79,80]$. The main drawback of this method is the lack of selectivity and sensitivity. HPLC coupled to ECD has the potential to be more selective than HPLC-UV or HPLC-fluorescent methods [13].

HPLC-Diode Array Detector. Comparatively to UV detection, DAD allows the simultaneous detection at different wavelengths [81]. Although HPLC-DAD is the most commonly used method for in vitro 3-NT analysis, it is not enough sensitive for in vivo quantitative analysis [65]. Recently, Selzle et al. [82] developed a simple and efficient HPLC-DAD method for the determination of the nitration degree of small amounts of the birch pollen allergen Bet $\mathrm{v}$ 1. This method can be photometrically calibrated by the amino acids Tyr and 3-NT without the need for nitrated protein standards. The study also reported that this new method can be used in the investigation of the reaction kinetics and mechanism of protein nitration [82].

HPLC-fluorescence detection. Since 3-NT is not a fluorescent compound, it can only be detected using a fluorescence detector after structural modifications, such as the reaction of the amino group of 3-NT with a suitable derivatizing reagent [80]. For instance, Pourfarzam et al. [32] used 4-fluoro-7-nitrobenzo-2-oxa1,3-diazole (NBD-F) as derivatization reagent. This reagent has been reported in several studies and the results obtained were comparable among them [32]. The fluorescent dyes used in the derivatization step of amino acids significantly improve the sensitivity and specificity of detection. NBD-F has a 10 -fold higher sensitivity than ortho-phthaldialdehyde (OPA) [56]. The limitation of this method is that several fluorescent compounds are produced during the derivatization process [80].

HPLC-Electrochemical detector. HPLC using ECD is relatively low-cost and has sufficient sensitivity for the measurement of 3-NT at moderately low basal levels found in most biological samples from healthy individuals. These ECD-based methods have the potential to be more selective than HPLC-UV or HPLC-fluorescence methods, with a sensitivity about 100 -fold greater [29].

The reproducibility of chromatogram signal intensity and retention time of 3-NT are determined by the quality of the C18 column used, as well as the appropriate maintenance of the electrochemical cell. Such reproducibility is ensured by (i) routine washing of the column with methanol, (ii) ensuring that potentials are not applied when the mobile phase is not flowing, and (iii) periodic reconditioning of the electrode when a performance loss is detected [29].

\subsubsection{Liquid chromatography-mass spectrometry methods}

One of the ways to overcome the limitations of HPLC is to couple it with an MS. This combination is advantageous for robust and unambiguous identification of compounds, especially when in the MS/MS mode [13,83]. Analytical methods based on MSmethodology are normally accepted as gold standards for the analysis of endogenous substances in biological fluids, owing to their high accuracy [1]. The advantage of this technique is that it does not require sample derivatization to increase its volatility, unlike gas chromatography-mass spectrometry (GC-MS), since it increases the likelihood of artifacts formation $[13,83]$.

Nevertheless, liquid chromatography-mass spectrometry (LCMS) does not offer the necessary selectivity for 3-NT measurement in biological sample, especially in human plasma [13,83]. One way to improve the selectivity and sensitivity for measurement is to use HPLC Hypercarb columns in triple-stage quadrupole LC-ESI (Electrospray ionization) -MS/MS. The Hypercarb columns are composed of porous spherical carbon particles and the separation is based on the stronger retention time for polar compounds [13].

Chen \& Chiu [84] developed a highly specific and accurate LC/ MS/MS assay that allows simultaneous analysis of protein-bound 3- 
Table 4

Different HPLC-based methods used for the determination of 3-NT in biological samples.

\begin{tabular}{|c|c|c|c|c|c|c|}
\hline Compound & Sample & Column $^{\mathrm{a}}$ & Eluents & $\begin{array}{l}\text { Flow } \\
\text { rate } \\
(\mathrm{mL} / \\
\min )\end{array}$ & $\begin{array}{l}\text { Detection } \\
\text { method }\end{array}$ & $\begin{array}{l}\text { LOD LOQ } \\
\text { for } 3-N T\end{array}$ \\
\hline 3-NT [24] & Animal spleen tissues & $\begin{array}{l}\text { Microtech Scientific } \\
\mathrm{C}_{18} \\
1.0 \times 50 ; 5\end{array}$ & $\begin{array}{l}50 \mathrm{mM} \mathrm{H}_{3} \mathrm{PO}_{4}, 50 \mathrm{mM} \text { citric acid, } 40 \mathrm{mg} / \mathrm{L} \text { EDTA, } \\
100 \mathrm{mg} / \mathrm{L} \text { octane sulfonic acid, } 5 \% \text { methanol }(\mathrm{v} / \mathrm{v})(\mathrm{pH} \\
3.1 \text { with } \mathrm{KOH})\end{array}$ & 0.05 & ECD & $\begin{array}{l}\text { N.S. } \\
\text { N.S. }\end{array}$ \\
\hline $\begin{array}{l}\text { 3-NT residues in } \\
\text { protein [79] }\end{array}$ & Bovine serum albumin and ovalbumin & $\begin{array}{l}\text { Grace Vydac } \\
2.1 \times 250 ; 5\end{array}$ & $0.1 \%(\mathrm{v} / \mathrm{v}) \mathrm{TFA}$ in water and $\mathrm{ACN}$ & 0.3 & $\begin{array}{l}\text { DAD } \\
280 \text { and } \\
357 \mathrm{~nm}\end{array}$ & $\begin{array}{l}4.3 \mathrm{pmol} \\
\text { N.S. }\end{array}$ \\
\hline 3-NT, Tyr [64] & Brain tissue & $\begin{array}{l}\text { Inertsil }^{\circledR} \text { ODS } C_{18} \\
4.6 \times 250 ; 5\end{array}$ & $50 \mathrm{mM}$ sodium acetate ( $\mathrm{pH} 4.2), 10 \%$ methanol (v/v) & 0.8 & $\begin{array}{l}\text { DAD } \\
278 \mathrm{~nm}\end{array}$ & $\begin{array}{l}6.7 \mathrm{nM} \\
\text { N.S. }\end{array}$ \\
\hline Tyr and 3-NT [25] & Gaseous nitrogen oxide species & $\begin{array}{l}\text { Inertsil ODS-2 } \\
4.6 \times 250 ; 5\end{array}$ & 0.5\% (v/v) acetic acid:methanol $(29: 1, \mathrm{v} / \mathrm{v})$ & 1.0 & $\begin{array}{l}\text { UV-VIS } \\
\text { detector } \\
280 \mathrm{~nm}\end{array}$ & $\begin{array}{l}\text { N.S. } \\
\text { N.S. }\end{array}$ \\
\hline 3-NT, Tyr [56] & Plasma & $\begin{array}{l}\text { Nova-Pak } \mathrm{C}_{18} \\
3.9 \times 150 ; 4\end{array}$ & $\begin{array}{l}\text { Mobile phase A: ACN and } 0.02 \mathrm{M} \text { phosphate buffer } \\
(\mathrm{pH} 6.5 ; 90: 10 \mathrm{v} / \mathrm{v}), 375 \mu \mathrm{L} / \mathrm{L} \text { TFA, } 5 \mathrm{~mL} / \mathrm{L} 2 \text {-propanol } \\
(\mathrm{pH}=4.5) \\
\text { Mobile phase B: ACN and } 0.02 \mathrm{M} \text { phosphate buffer } \\
(\mathrm{pH} 6.5 ; 10: 90 \mathrm{v} / \mathrm{v}), 500 \mu \mathrm{L} / \mathrm{L} \text { TFA (pH 3.5) }\end{array}$ & $\left(34{ }^{\circ} \mathrm{C}\right)$ & $\begin{array}{l}\text { UV } \\
540 \mathrm{~nm}\end{array}$ & $\begin{array}{l}0.5 \mathrm{nM} \\
\text { N.S. }\end{array}$ \\
\hline 3-NT [85] & Plasma & $\begin{array}{l}\text { SD ODS } \\
3.0 \times 150 ; 5\end{array}$ & $\begin{array}{l}100 \mathrm{mM} \text { phosphate buffer solution, } 5 \% \text { methanol }(\mathrm{v} / \\
\mathrm{v})\end{array}$ & $\begin{array}{l}0.5 \\
\left(25^{\circ} \mathrm{C}\right)\end{array}$ & ECD & $\begin{array}{l}<10 \text { fmol } \\
\text { N.S. }\end{array}$ \\
\hline $\begin{array}{l}\text { Free 3-NT Assay } \\
\quad[32]\end{array}$ & Plasma & $\begin{array}{l}\text { Nova-Pak } \mathrm{C}_{18} \\
3.9 \times 150 ; 4\end{array}$ & $\begin{array}{l}\text { Sodium phosphate buffer }(0.1 \mathrm{M}, \mathrm{pH} 7.2) \text {, methanol } \\
(52.5: 47.5 \mathrm{v} / \mathrm{v})\end{array}$ & 1.0 & $\begin{array}{l}\text { UV } \\
470 \text { and } \\
540 \mathrm{~nm}\end{array}$ & $\begin{array}{l}0.2 \mathrm{nM} \\
0.6 \mathrm{nM}\end{array}$ \\
\hline 3-NT [73] & Proteins from blood plasma & $\begin{array}{l}\text { Two ultrasphere } \\
\text { ODS } \\
4.6 \times 150 ; 3 \\
4.6 \times 46 ; 5\end{array}$ & $50 \mathrm{mM}$ sodium acetate ( $\mathrm{pH} 4.7), 5 \%$ methanol (v/v) & 0.7 & $\begin{array}{l}\text { UV } \\
280 \mathrm{~nm}\end{array}$ & $\begin{array}{l}1 \mathrm{pmol} \\
\approx 400 \mathrm{pmol}\end{array}$ \\
\hline 3-NT [78] & Rat plasma & $\begin{array}{l}\text { SC-50ODS } \\
3.0 \times 150 ; 5\end{array}$ & $\begin{array}{l}200 \mathrm{mM} \text { phosphate buffer containing } 5 \mathrm{mg} / \mathrm{mL} \text { EDTA, } \\
2 \% \text { ACN }\end{array}$ & 0.5 & ECD & $\begin{array}{l}\text { N.S. } \\
\text { N.S. }\end{array}$ \\
\hline Free 3-NT [58] & Serum & $\begin{array}{l}C_{18} \text { reversed phase } \\
\text { column } \\
4.6 \times 250 ; 5\end{array}$ & $\begin{array}{l}500 \mathrm{mM} \text { potassium phosphate buffer } \\
(\mathrm{pH} 3.5), 10 \% \text { methanol }(\mathrm{v} / \mathrm{v})\end{array}$ & 0.8 & $\begin{array}{l}\text { UV } \\
274 \mathrm{~nm}\end{array}$ & $\begin{array}{l}0.20 \mathrm{nM} \\
\text { N.S. }\end{array}$ \\
\hline 3-NT [63] & Sputum and saliva & $\begin{array}{l}\mathrm{C}_{18} \text { reversed phase } \\
\text { column } \\
3.0 \times 150 ; 5\end{array}$ & $\begin{array}{l}100 \mathrm{mM} \text { sodium phosphate buffer } \\
(\mathrm{pH} 5.0), 5 \% \text { methanol }(\mathrm{v} / \mathrm{v})\end{array}$ & 0.5 & ECD & $\begin{array}{l}10 \text { fmol } \\
\text { N.S. }\end{array}$ \\
\hline $\begin{array}{l}\text { Tyr and 3-NT } \\
\text { metabolites [46] }\end{array}$ & $\begin{array}{l}\text { Undifferentiated human } \\
\text { teratocarcinoma NT2 and rat } \\
\text { pheochromocytoma PC12 cell lines }\end{array}$ & $\begin{array}{l}\text { Octadodecyl silica } \\
\text { gel reverse-phase } \\
\text { column } \\
4.6 \times 250 ; 5\end{array}$ & $\begin{array}{l}0.1 \% \text { TFA in ultra pure water (solvent A) and } 100 \% \\
\text { ACN (solvent B) }\end{array}$ & 1.0 & $\begin{array}{l}\text { DAD } \\
215,275 \\
365 \mathrm{~nm}\end{array}$ & $\begin{array}{l}\text { N.S. } \\
\text { N.S. }\end{array}$ \\
\hline $\begin{array}{l}\text { 3-NT, } p \text {-nitro-L- } \\
\text { phenylalanine, } \\
\text { and L-Tyr [59] }\end{array}$ & Urine & $\begin{array}{l}\text { Nucleosil } 100-5 C_{18} \\
4.0 \times 250 ; 5\end{array}$ & $\begin{array}{l}50 \mathrm{mM}\left(\mathrm{NH}_{4}\right)_{2} \mathrm{SO}_{4} \text { in water-methanol }(95: 5, \mathrm{v} / \mathrm{v})(\mathrm{pH} \\
5.5)\end{array}$ & 1.0 & $\begin{array}{l}\text { UV } \\
276 \mathrm{~nm}\end{array}$ & $\begin{array}{l}6 \text { pmol } \\
\text { N.A. }\end{array}$ \\
\hline
\end{tabular}

ACN, acetonitrile; EDTA, ethylenediamine tetraacetic acid; TFA, trifluoroacetic acid; LOD, limit of detection; LOQ limit of quantification; N.S.,not stated.

a Column dimensions in the following order: internal diameter (in $\mathrm{mm}$ ) $\mathrm{x}$ length (in $\mathrm{mm}$ ); particle size (in $\mu \mathrm{m}$ ).

NT and 3-bromotyrosine (3-BT) in human urine. This proteins function as non-invasive biomarkers for in vivo PTN and bromination.

Table 5 describes several liquid chromatography-based methods/protocols for determination of 3-NT in biological samples that have been published over the last year.

\subsubsection{Gas chromatography-mass spectrometry methods}

GC-MS methodology is used for the analysis of volatile and thermally stable small molecules [13]. When molecules to be analysed, such as amino acids, do not meet these features, a further derivatization step is required. In this sense, analysis of 3-NT by this methodology requires prior chemical derivatization and/or modification of the functional groups (i.e., $\mathrm{p}-\mathrm{OH}, \mathrm{a}-\mathrm{NH}_{2}$, and $\mathrm{COOH}$ ) to increase volatility and thermal stability (i.e., reduction of the aromatic $\mathrm{NO}_{2}$ group). In addition, derivatization improves GC and MS behaviour of 3-NT [83]. Derivatization, however, often accounts for 3-NT artifact formation, which is may be responsible for high variation of basal plasmatic 3-NT levels [1]. Nevertheless, GCtandem MS is described as a methodology that allows the accurate quantification of free 3-NT in human plasma at basal levels. GC- tandem MS is more accurate than GC-MS [1,59]. Table 6 summarises different gas chromatography-based methods for determination of 3-NT in biological samples.

The GC-MS and GC-MS/MS methods for the analysis of 3-NT involve the preparation of perfluorinated derivatives. Perfluorinated compounds are strong electron-capturing species, thus offering assays of particularly high sensitivity [83].

Gaut et al. [87] reported that GC-MS was 100-fold more sensitive than LC-tandem MS for the analysis of 3-NT. The major drawback of this method is that 3-NT is not suitably separated from Tyr, nitrite and nitrate prior to GC-MS analysis or derivatization. Such separation could potentially be achieved, for instance, by HPLC [14].

In the study performed by Söderling et al. [54], the derivatization method used was based on the reduction of the nitro group of 3-NT by dithionite, heptafluorobutyric acylation and subsequent methyl derivatization. Their results demonstrated excellent GC and MS properties, namely low background and a favourable fragmentation pattern [54].

In fact, the major strategies used to avoid artifacts formation are (i) isolation of 3-NT by SPE and HPLC; (ii) reduction of 3-NT to 
Table 5

Different liquid chromatography-based methods used for the determination of 3-NT in biological samples.

\begin{tabular}{|c|c|c|c|c|c|c|}
\hline Compound & Sample & Column $^{\mathrm{a}}$ & Eluents & Flow rate & $\begin{array}{l}\text { Detection } \\
\text { method }\end{array}$ & $\begin{array}{l}\text { LOD LOQ for } \\
\text { 3-NT }\end{array}$ \\
\hline $\begin{array}{l}\text { Free amino acid and } \\
\text { protein 3-NT [57] }\end{array}$ & $\begin{array}{l}\text { Biological } \\
\text { fluids }\end{array}$ & $\begin{array}{l}\text { Immunoaffinity } \\
\text { column: Targa } \\
4.6 \times 30 \\
\mathrm{C}_{18} \text { reversed-phase } \\
\text { column: Betasil } \\
2.1 \times 100 ; 5\end{array}$ & $\begin{array}{l}\text { Immunoaffinity column: } 1 \% \text { formic acid } \\
\mathrm{C}_{18} \text { reversed-phase column: } 100 \% 10 \mathrm{mM} \text { ammonium } \\
\text { acetate acetonitrile }\end{array}$ & $\begin{array}{l}\text { Immunoaffinity } \\
\text { column: } 1 \mathrm{~mL} / \mathrm{min} \\
\mathrm{C}_{18} \text { reversed-phase } \\
\text { column: } 0.3 \mathrm{~mL} / \mathrm{min}\end{array}$ & $\begin{array}{l}\text { Immunoaffinity } \\
\text { LC-MS/MS }\end{array}$ & $\begin{array}{l}5 \mathrm{pg} / \mathrm{mL} \\
(22.1 \mathrm{pM}) \\
5 \mathrm{pg} / \mathrm{mL} \\
\text { (Lower } \\
\text { LOQ) }\end{array}$ \\
\hline 3-NT [15] & $\begin{array}{l}\text { Microglial } \\
\text { Cell Lysate }\end{array}$ & $\begin{array}{l}\text { EASY-Spray }^{\mathrm{TM}} \\
250 \times 0.075 ; 2\end{array}$ & $\begin{array}{l}0.1 \% \text { formic acid in water (mobile phase } \mathrm{A} \text { ) and } 0.1 \% \\
\text { formic acid in ACN (mobile phase solvent B) }\end{array}$ & $350 \mathrm{~nL} / \mathrm{min}$ & LC-MS/MS & $\begin{array}{l}\text { N.S. } \\
\text { N.S. }\end{array}$ \\
\hline Free 3-NT [86] & Plasma & $\begin{array}{l}\text { Altima HP } \\
100 \times 2.1 \mathrm{~mm} ; 3 \\
\text { Kinetex } \\
100 \times 2.1 ; 2.6\end{array}$ & $\begin{array}{l}0.01 \% \text { acetic acid in ultrapure water (mobile phase } \mathrm{A} \text { ) } \\
+ \\
0.01 \% \text { acetic acid in } \mathrm{ACN} \text { (mobile phase B) }\end{array}$ & $0.2 \mathrm{~mL} / \mathrm{min}$ & LC-MS/MS & $\begin{array}{l}0.034 \mathrm{nM} \\
0.112 \mathrm{nM}\end{array}$ \\
\hline $\begin{array}{l}\text { 3-chlorotyrosine, 3- } \\
\text { BT, and 3-NT [87] }\end{array}$ & Plasma & $\begin{array}{l}\mathrm{C}_{18} \text { reversed phase } \\
\text { column Zorbax } \\
1.0 \times 150 ; 5\end{array}$ & $\begin{array}{l}\text { Methanol/water/acetic acid }(4 / 95 / 1, \mathrm{v} / \mathrm{v} / \mathrm{v}, \mathrm{pH} 3 \text { - solvent } \\
\text { A) } \\
+ \\
\text { methanol/water/acetic acid }(95 / 4 / 1, \mathrm{v} / \mathrm{v} / \mathrm{v}, \mathrm{pH}=3.2 \\
\text {-solvent B) }\end{array}$ & $0.05 \mathrm{~mL} / \mathrm{min}$ & LC-MS/MS & $\begin{array}{l}3.2 \mathrm{fmol} \\
\text { N.S. }\end{array}$ \\
\hline 3-NT [88] & $\begin{array}{l}\text { Plasma and } \\
\text { Urine }\end{array}$ & $\begin{array}{l}\text { HypercarbTM } \\
2.1 \times 50 ; 5\end{array}$ & $\begin{array}{l}0.1 \% \text { TFA with a linear } \\
\text { gradient of } 10-50 \% \text { acetonitrile }\end{array}$ & $0.2 \mathrm{~mL} / \mathrm{min}$ & LC-MS/MS & $\begin{array}{l}0.022 \mathrm{pmol} \\
\text { N.S. }\end{array}$ \\
\hline 3-NT and 3-BT [84] & Urine & $\begin{array}{l}\text { Reversed phase } C_{18} \\
\text { column } \\
2.0 \times 150 ; 5\end{array}$ & $\begin{array}{l}0.01 \% \text { formic acid ( } \mathrm{pH} 3.2 \text { ) to } 25 \% \text { methanol in } 0.01 \% \\
\text { formic acid }\end{array}$ & $0.2 \mathrm{~mL} / \mathrm{min}$ & LC-ESI/MS/MS & $\begin{array}{l}44 \mathrm{fmol} \\
\text { N.S. }\end{array}$ \\
\hline $\begin{array}{l}\text { 3-NT, 3-BT, } \\
\text { Dibromotyrosine } \\
\text { [89] }\end{array}$ & Urine & $\begin{array}{l}\text { ODS-SR } \\
2 \times 150 ; 5\end{array}$ & $0.05 \%$ formic acid $/ \mathrm{CH}_{3} \mathrm{CN}(95: 5)$ & Not stated & LC/MS/MS & $\begin{array}{l}1 \mathrm{nM} \\
\text { N.S. }\end{array}$ \\
\hline
\end{tabular}

ACN, acetonitrile; TFA, trifluoroacetic acid; LOD, limit of detection; LOQ limit of quantification; N.S., not stated.

a Column dimensions in the following order: internal diameter (in $\mathrm{mm}$ ) x length (in $\mathrm{mm}$ ); particle size (in $\mu \mathrm{m}$ ).

Table 6

Different gas chromatography-based methods used for the determination of 3-NT in biological samples.

\begin{tabular}{|c|c|c|c|c|c|}
\hline Compound & Sample & Column $^{\mathrm{a}}$ & Eluents & $\begin{array}{l}\text { Detection } \\
\text { method }\end{array}$ & $\begin{array}{l}\text { LOD LOQ for } \\
\text { 3-NT }\end{array}$ \\
\hline 3-NT [60] & CSF & $\begin{array}{l}\text { DB-1 MS } \\
\text { column } \\
15 \times 0.32 \text {; } \\
0.25\end{array}$ & Helium (3psi); Methane (750-800 Pa) & GC-MS/MS & $\begin{array}{l}\text { N.S. } \\
\text { N.S. }\end{array}$ \\
\hline Free 3-NT [62] & $\begin{array}{l}\text { Exhaled breath } \\
\text { condensate (EBC) }\end{array}$ & $\begin{array}{l}\text { DB5-MS } \\
\text { column } \\
30 \times 0.25 \\
0.25\end{array}$ & Helium (38 kPa); Methane (0.97-0.99 kPa) & $\begin{array}{l}\mathrm{GC} / \mathrm{NICI} / \\
\text { tandem MS }\end{array}$ & $\begin{array}{l}0.56 \mathrm{pM} \\
1.70 \mathrm{pM}\end{array}$ \\
\hline $\begin{array}{l}\text { Protein-associated 3-NT and 3- } \\
\text { nitrotyrosinoalbumin [55] }\end{array}$ & Plasma & $\begin{array}{l}\text { Optima 5- } \\
\text { MS } \\
30 \times 0.25 \\
0.25\end{array}$ & Helium (55 kPa); Methane (530 Pa) and Argon (0.27 Pa) & GC-MS/MS & $\begin{array}{l}\text { N.S. } \\
\text { N.S. }\end{array}$ \\
\hline 3-NT [54] & Plasma & $\begin{array}{l}\text { DB5-MS } \\
\text { column } \\
30 \times 0.25 \\
0.25\end{array}$ & Helium (41 kPa); Methane (0.27-1.1 kPa) & GC-MS/MS & $\begin{array}{l}0.03 \mathrm{nM} \\
0.3 \mathrm{nM}\end{array}$ \\
\hline 3-NT [59] & Urine & $\begin{array}{l}\text { Optima 5- } \\
\text { MS } \\
30 \times 0.25 \text {; } \\
0.25\end{array}$ & $\begin{array}{l}\text { Helium ( } 55 \mathrm{kPa}) \text {; Methane ( } 530 \mathrm{~Pa}) \text { and Argon ( } 0.27 \mathrm{~Pa} \\
\text { collision pressure) }\end{array}$ & GC-MS/MS & $\begin{array}{l}4 \mathrm{amol} \\
125 \mathrm{pM}\end{array}$ \\
\hline
\end{tabular}

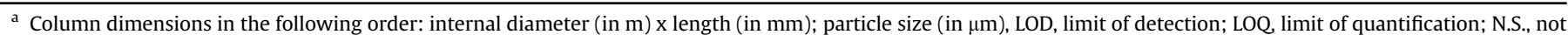
stated.

3-amimotyrosine before sample derivatization, thus artifactual nitration of Tyr does not influence the measurement; (iii) use of high concentrations of reactive aromatic compounds (i.e., phenol) to capture nitrosating species; and (iv) quantification of artifactual 3-NT formation, by incorporating stable-isotope labelled Tyr (e.g., 13 C6 -Tyr) into each sample [83]. Overall, the main disadvantage of using chromatographic methods is that they involve time-consuming sample preparation procedures [69].

\section{Conclusions}

As previously stated, nitration of proteins is a common process that occurs under physiological conditions. On the other hand, a significant increase in the extent of this process, induced by an increased nitrative stress state, has been associated with a wide range of diseases.

3-NT has been pointed out as a potential biological tool for the therapeutic monitoring of this process. However, PTN is typically a low-yield process, thus it requires sensitive analytical methods for its quantification. Regarding this, the quantification of 3-NT poses some 
challenges, namely: (i) endogenous levels are extremely low, and near the limits of detection/quantitation for most of the currently available analytical methods; (ii) 3-NT must be detected and quantified in the presence of a vast excess of Tyr, thus requiring high selective method (avoiding interferences from other closely related molecules; and (iii) changes in 3-NT levels may be very slight.

In summary, a wide range of methods for 3-NT detection and quantification has been developed during the last years, all of them presenting positive and negative aspects. Regarding ELISA-based methods, and despite being the least time-consuming and straightforward methods, it has become clear that they do not provide the most accurate results. On the other hand, and in relation to chromatographic methods, they seem to be very accurate, showing very good sensibility and specificity. GC-based methods exhibit the highest sensibility in the quantification of 3-NT. However, and owing to 3-NT chemical properties, a derivatization step prior analysis is required, which ends up being time-consuming for the analyst. Moreover, derivatization reactions often induce artifacts formation, which may further influence the final analysis. Conversely, HPLC does not require such derivatization step, despite being not as accurate as GC. Regarding this matter, and in order to improve both sensitivity and specificity of HPLC-based methods, further optimization of the protocols that have been described is clearly needed.

\section{Conflict of interest}

The author declares no conflict of interest.

\section{Acknowledgements}

This work was supported by an Integration into Scientific Research Grant (B Int-ICD/IPP-BST/CISA/01/2014) funded by Centro de Investigação em Saúde e Ambiente (CISA).

\section{References}

[1] D. Tsikas, K. Caidahl, Recent methodological advances in the mass spectrometric analysis of free and protein-associated 3-nitrotyrosine in human plasma, J. Chromatogr. B Anal. Technol. Biomed. Life Sci. 814 (2005) 1-9.

[2] E. Ho, K. Karimi Galougahi, C.-C. Liu, R. Bhindi, G.A. Figtree, Biological markers of oxidative stress: applications to cardiovascular research and practice, Redox Biol. 1 (2013) 483-491.

[3] N.S. Bryan, M.B. Grisham, Methods to detect nitric oxide and its metabolites in biological samples, Free Radic. Biol. Med. 43 (2007) 645-657.

[4] D. Shah, N. Mahajan, S. Sah, S.K. Nath, B. Paudyal, Oxidative stress and its biomarkers in systemic lupus erythematosus, J. Biomed. Sci. 21 (2014), 23-23.

[5] S. de M Bandeira, L.J.S. da Fonseca, G. da S Guedes, L.A. Rabelo, M.O.F. Goulart, S.M.L. Vasconcelos, Oxidative stress as an underlying contributor in the development of chronic complications in diabetes mellitus, Int. J. Mol. Sci. 14 (2013) 3265-3284.

[6] D.P. Jones, Redefining oxidative stress, Antioxid. Redox Signal. 8 (2006) $1865-1879$.

[7] K. Ogino, D.-H. Wang, Biomarkers of oxidative/nitrosative stress: an approach to disease prevention. Acta Med. Okayama 61 (2007) 181-189.

[8] I. Dalle-Donne, R. Rossi, R. Colombo, D. Giustarini, A. Milzani, Biomarkers of oxidative damage in human disease, Clin. Chem. 52 (2006) 601-623.

[9] M. Safinowski, B. Wilhelm, T. Reimer, A. Weise, N. Thomé, H. Hänel, T. Forst, A. Pfützner, Determination of nitrotyrosine concentrations in plasma samples of diabetes mellitus patients by four different immunoassays leads to contradictive results and disqualifies the majority of the tests, Clin. Chem. Lab. Med. CCLM/FESCC 47 (2009) 483-488.

[10] H. Ahsan, 3-Nitrotyrosine: a biomarker of nitrogen free radical species modified proteins in systemic autoimmunogenic conditions, Hum. Immunol. 74 (2013) 1392-1399.

[11] R. Radi, Protein tyrosine nitration: biochemical mechanisms and structural basis of functional effects, Acc. Chem. Res. 46 (2013) 550-559.

[12] S. Bartesaghi, G. Ferrer-Sueta, G. Peluffo, V. Valez, H. Zhang, B. Kalyanaraman, R. Radi, Protein tyrosine nitration in hydrophilic and hydrophobic environments, Amino Acids 32 (2007) 501-515.

[13] H. Ryberg, K. Caidahl, Chromatographic and mass spectrometric methods for quantitative determination of 3-nitrotyrosine in biological samples and their application to human samples, J. Chromatogr. B Anal. Technol. Biomed. Life Sci. 851 (2007) 160-171.

[14] D. Tsikas, Analytical methods for 3-nitrotyrosine quantification in biological samples: the unique role of tandem mass spectrometry, Amino Acids 42 (2012) 45-63.

[15] K.W. Seeley, A.R. Fertig, C.P. Dufresne, J.P.C. Pinho, S.M. Stevens Jr., Evaluation of a method for nitrotyrosine site identification and relative quantitation using a stable isotope-labeled nitrated spike-in standard and high resolution fourier transform MS and MS/MS analysis, Int. J. Mol. Sci. 15 (2014) 6265-6285.

[16] K. Jiao, S. Mandapati, P.L. Skipper, S.R. Tannenbaum, J.S. Wishnok, Site-selective nitration of tyrosine in human serum albumin by peroxynitrite, Anal Biochem. 293 (2001) 43-52.

[17] T.R. Larsen, N. Bache, J.B. Gramsbergen, P. Roepstorff, Identification of nitrotyrosine containing peptides using combined fractional diagonal chromatography (COFRADIC) and off-line nano-LC-MALDI, J. Am. Soc. Mass Spectrom. 22 (2011) 989-996.

[18] W.-S. Yeo, S.J. Lee, J.R. Lee, K.P. Kim, Nitrosative protein tyrosine modifications: biochemistry and functional significance, BMB Rep. 41 (2008) 194-203.

[19] S. Shiva, Nitrite: a physiological store of nitric oxide and modulator of mitochondrial function, Redox Biol. 1 (2013) 40-44.

[20] R. Radi, Nitric oxide, oxidants, and protein tyrosine nitration, Proc. Natl. Acad. Sci. U. S. A. 101 (2004) 4003-4008.

[21] N.B. Surmeli, N.K. Litterman, A.-F. Miller, J.T. Groves, Peroxynitrite mediates active site tyrosine nitration in manganese superoxide dismutase. Evidence of a role for the carbonate radical anion, J. Am. Chem. Soc. 132 (2010) $17174-17185$.

[22] S. Goldstein, G. Merényi, The chemistry of peroxynitrite: implications for biological activity, Methods Enzym. 436 (2008) 49-61.

[23] R. Radi, Peroxynitrite, a stealthy biological oxidant, J. Biol. Chem. 288 (2013) 26464-26472.

[24] F.S. Bircan, B. Balabanli, N. Turkozkan, G. Ozan, Effects of taurine on nitric oxide and 3-nitrotyrosine levels in spleen during endotoxemia, Neurochem. Res. 36 (2011) 1978-1983.

[25] K. Kikugawa, K. Hiramoto, T. Ohkawa, Effects of oxygen on the reactivity of nitrogen oxide species including peroxynitrite, Biol. Pharm. Bull. 27 (2004) $17-23$.

[26] Y.-C. Sun, P.-Y. Chang, K.-C. Tsao, T.-L. Wu, C.-F. Sun, L.L. Wu, J.T. Wu, Establishment of a sandwich ELISA using commercial antibody for plasma or serum 3-nitrotyrosine (3NT). Elevation in inflammatory diseases and complementary between 3NT and myeloperoxidase, Clin. Chim. Acta Int. J. Clin. Chem. 378 (2007) 175-180.

[27] A. Daiber, T. Münzel, Increased circulating levels of 3-nitrotyrosine autoantibodies: marker for or maker of cardiovascular disease? Circulation 126 (2012) $2371-2373$

[28] S. Kagota, K. Fukushima, K. Umetani, Y. Tada, N. Nejime, K. Nakamura, H. Mori K. Sugimura, M. Kunitomo, K. Shinozuka, Coronary vascular dysfunction promoted by oxidative-nitrative stress in SHRSP.Z-Lepr(fa)/IzmDmcr rats with metabolic syndrome, Clin. Exp. Pharmacol. Physiol. 37 (2010) 1035-1043.

[29] T. Nuriel, R.S. Deeb, D.P. Hajjar, S.S. Gross, Protein 3-nitrotyrosine in complex biological samples: quantification by high-pressure liquid chromatography/ electrochemical detection and emergence of proteomic approaches for unbiased identification of modification sites, Methods Enzym. 441 (2008) 1-17.

[30] V.A. Yakovlev, R.B. Mikkelsen, Protein tyrosine nitration in cellular signa transduction pathways, J. Recept. Signal Transduct. Res. 30 (2010) 420-429.

[31] M.H. Shishehbor, R.J. Aviles, M.-L. Brennan, X. Fu, M. Goormastic, G.L. Pearce, N. Gokce, J.F. Keaney Jr., M.S. Penn, D.L. Sprecher, J.A. Vita, S.L. Hazen, Association of nitrotyrosine levels with cardiovascular disease and modulation by statin therapy, JAMA, J. Am. Med. Assoc. 289 (2003) 1675-1680.

[32] M. Pourfarzam, A. Movahedian, N. Sarrafzadegan, G. Basati, S.Z. Samsamshariat, Association between plasma myeloperoxidase and free 3nitrotyrosine levels in patients with coronary artery disease, Int. J. Clin. Med. (2013) 158-164.

[33] N. Sucu, A. Unlü, L. Tamer, B. Aytacoglu, B. Ercan, M. Dikmengil, U. Atik, 3Nitrotyrosine in Atherosclerotic Blood Vessels, Clinical Chemistry and Laboratory Medicine: CCLM/FESCC, vol. 41, 2003, pp. 23-25.

[34] R.K. Upmacis, Atherosclerosis: A Link between Lipid Intake and Protein Tyrosine Nitration, Lipid Insights, vol. 2008, 2008, 75-75.

[35] N. Voraphani, M.T. Gladwin, J.B. Trudeau, S.E. Wenzel, P6: Th1/Th2 Cytokines promote Nitrite/H2O2-mediated tyrosine nitration in airway epithelial cells: potential role in severe asthma, Nitric Oxide 31 (Supplement 1) (2013) S15-S16.

[36] K. Shimizu, F. Ogawa, E. Muroi, T. Hara, K. Komura, S.J. Bae, S. Sato, Increased serum levels of nitrotyrosine, a marker for peroxynitrite production, in systemic sclerosis, Clin. Exp. Rheumatol. 25 (2007) 281-286.

[37] L. Kruidenier, I. Kuiper, C.B.H.W. Lamers, H.W. Verspaget, Intestinal oxidative damage in inflammatory bowel disease: semi-quantification, localization, and association with mucosal antioxidants, J. Pathol. 201 (2003) 28-36.

[38] R.-J. Teng, T.-J. Wu, C.G. Bisig, A. Eis, K.A. Pritchard, G.G. Konduri, Nitrotyrosine impairs angiogenesis and uncouples eNOS activity of pulmonary artery endothelial cells isolated from developing sheep lungs, Pediatr. Res. 69 (2011) $112-117$.

[39] T.P. Misko, M.R. Radabaugh, M. Highkin, M. Abrams, O. Friese, R. Gallavan, C. Bramson, M.P. Hellio Le Graverand, L.S. Lohmander, D. Roman, Characterization of nitrotyrosine as a biomarker for arthritis and joint injury, Osteoarthr. Cartil. OARS Osteoarthr. Res. Soc. 21 (2013) 151-156.

[40] P.G. Winyard, B. Ryan, P. Eggleton, A. Nissim, E. Taylor, M.L. Lo Faro, T. Burkholz, K.E. Szabó-Taylor, B. Fox, N. Viner, R.C. Haigh, N. Benjamin, 
A.M. Jones, M. Whiteman, Measurement and meaning of markers of reactive species of oxygen, nitrogen and sulfur in healthy human subjects and patients with inflammatory joint disease, Biochem. Soc. Trans. 39 (2011) 1226-1232.

[41] E. Baraldi, G. Giordano, M.F. Pasquale, S. Carraro, A. Mardegan, G. Bonetto, C. Bastardo, F. Zacchello, S. Zanconato, 3-Nitrotyrosine, a marker of nitrosative stress, is increased in breath condensate of allergic asthmatic children, Allergy 61 (2006) 90-96.

[42] S. Parakh, D.M. Spencer, M.A. Halloran, K.Y. Soo, J.D. Atkin, Redox regulation in amyotrophic lateral sclerosis, Oxidative Med. Cell. Longev. 2013 (2013) 408681.

[43] D.M.F. Mendonça, S.C.S. Martins, R. Higashi, M.N. Muscara, V.M. Neto L. Chimelli, A.M.B. Martinez, Neurofilament Heavy Subunit in Cerebrospina Fluid: A Biomarker of Amyotrophic Lateral Sclerosis?, Amyotrophic Lateral Sclerosis, vol. 12, Official Publication Of The World Federation Of Neurology Research Group On Motor Neuron Diseases, 2011, pp. 144-147.

[44] A. Dietrich-Muszalska, B. Olas, R. Głowacki, E. Bald, Oxidative/nitrative modifications of plasma proteins and thiols from patients with schizophrenia, Neuropsychobiology 59 (2009) 1-7.

[45] F. Mangialasche, M.C. Polidori, R. Monastero, S. Ercolani, C. Camarda, R. Cecchetti, P. Mecocci, Biomarkers of oxidative and nitrosative damage in Alzheimer's disease and mild cognitive impairment, Ageing Res. Rev. 8 (2009) 285-305.

[46] B. Blanchard-Fillion, D. Prou, M. Polydoro, D. Spielberg, E. Tsika, Z. Wang, S.L. Hazen, M. Koval, S. Przedborski, H. Ischiropoulos, Metabolism of 3nitrotyrosine induces apoptotic death in dopaminergic cells, J. Neurosci. Off. J. Soc. Neurosci. 26 (2006) 6124-6130.

[47] S. Rose, S. Melnyk, O. Pavliv, S. Bai, T.G. Nick, R.E. Frye, S.J. James, Evidence of oxidative damage and inflammation associated with low glutathione redox status in the autism brain, Transl. Psychiatry 2 (2012) e134.

[48] G. Morris, M. Maes, Oxidative and nitrosative stress and immuneinflammatory pathways in patients with myalgic encephalomyelitis (ME) chronic fatigue syndrome (CFS), Curr. Neuropharmacol. 12 (2014) 168-185.

[49] L. Shu, A. Vivekanandan-Giri, S. Pennathur, B.E. Smid, J.M.F. Aerts, C.E.M. Hollak, J.A. Shayman, Establishing 3-nitrotyrosine as a biomarker for the vasculopathy of Fabry disease, Kidney Int. 86 (1) (2014) 58-66.

[50] I. Jialal, S. Devaraj, B. Adams-Huet, X. Chen, H. Kaur, Increased cellular and circulating biomarkers of oxidative stress in nascent metabolic syndrome, J. Clin. Endocrinol. Metab. 97 (2012) E1844-E1850.

[51] R.C. Thuraisingham, C.A. Nott, S.M. Dodd, M.M. Yaqoob, Increased nitrotyrosine staining in kidneys from patients with diabetic nephropathy, Kidney Int. 57 (2000) 1968-1972.

[52] S. Devaraj, A.T. Cheung, I. Jialal, S.C. Griffen, D. Nguyen, N. Glaser, T. Aoki, Evidence of increased inflammation and microcirculatory abnormalities in patients with type 1 diabetes and their role in microvascular complications, Diabetes 56 (2007) 2790-2796.

[53] M. Dhiman, E.S. Nakayasu, Y.H. Madaiah, B.K. Reynolds, J.-J. Wen, I.C. Almeida, N.J. Garg, Enhanced nitrosative stress during Trypanosoma cruzi infection causes nitrotyrosine modification of host proteins: implications in Chagas disease, Am. J. Pathol. 173 (2008) 728-740.

[54] A.-S. Söderling, H. Ryberg, A. Gabrielsson, M. Lärstad, K. Torén, S. Niari K. Caidahl, A derivatization assay using gaschromatography/negative chemical ionization tandem mass spectrometry to quantify 3-nitrotyrosine in human plasma, J. Mass Spectrom. JMS 38 (2003) 1187-1196.

[55] D. Tsikas, E. Schwedhelm, F.K. Stutzer, F.M. Gutzki, I. Rode, C. Mehls, J.C. Frölich, Accurate quantification of basal plasma levels of 3-nitrotyrosine and 3-nitrotyrosinoalbumin by gas chromatography-tandem mass spectrometry, J. Chromatogr. B Anal. Technol. Biomed. Life Sci. 784 (2003) 77-90.

[56] W.-Z. Zhang, C. Lang, D.M. Kaye, Determination of plasma free 3-nitrotyrosine and tyrosine by reversed-phase liquid chromatography with 4-fluoro-7 nitrobenzofurazan derivatization, Biomed. Chromatogr. BMC 21 (2007) 273-278.

[57] M.R. Radabaugh, O.V. Nemirovskiy, T.P. Misko, P. Aggarwal, W.R. Mathews, Immunoaffinity liquid chromatography-tandem mass spectrometry detection of nitrotyrosine in biological fluids: development of a clinically translatable biomarker, Anal. Biochem. 380 (2008) 68-76.

[58] F. Khan, A.A. Siddiqui, R. Ali, Measurement and significance of 3-nitrotyrosine in systemic lupus erythematosus, Scand. J. Immunol. 64 (2006) 507-514.

[59] D. Tsikas, A. Mitschke, M.-T. Suchy, F.-M. Gutzki, D.O. Stichtenoth, Determination of 3-nitrotyrosine in human urine at the basal state by gas chromatography-tandem mass spectrometry and evaluation of the excretion after oral intake, J. Chromatogr. B Anal. Technol. Biomed. Life Sci. 827 (2005) $146-156$.

[60] H. Ryberg, A.-S. Söderling, P. Davidsson, K. Blennow, K. Caidahl, L.I. Persson, Cerebrospinal fluid levels of free 3-nitrotyrosine are not elevated in the majority of patients with amyotrophic lateral sclerosis or Alzheimer's disease, Neurochem. Int. 45 (2004) 57-62.

[61] A. Seven, M. Aslan, S. Incir, A. Altintas, Evaluation of oxidative and nitrosative stress in relapsing remitting multiple sclerosis: effect of corticosteroid therapy, Folia neuropathologica/Association of Polish Neuropathologists and Medical Research Centre, Pol. Acad. Sci. 51 (2013) 58-64.

[62] M. Lärstad, A.-S. Söderling, K. Caidahl, A.-C. Olin, Selective quantification of free 3-nitrotyrosine in exhaled breath condensate in asthma using gas chromatography/tandem mass spectrometry, Nitric Oxide Biol. Chem. Off. J. Nitric Oxide Soc. 13 (2005) 134-144.

[63] K. Ueshima, Y. Minakata, H. Sugiura, S. Yanagisawa, T. Ichikawa, K. Akamatsu,
T. Hirano, M. Nakanishi, K. Matsunaga, T. Yamagata, M. Ichinose, The influence of free 3-nitrotyrosine and saliva on the quantitative analysis of proteinbound 3-nitrotyrosine in sputum, Anal. Chem. Insights 2 (2007) 1-7.

[64] D. Guvenç, A. Aksoy, Y. Kursad, E. Atmaca, O. Yavuz, 3-nitrotyrosine levels in dichlorvos-induced neurotoxicity, Arh. Hig. Rada Toksikol. 65 (2014) 109-112.

[65] L. Mergola, S. Scorrano, R. Del Sole, M.R. Lazzoi, G. Vasapollo, Developments in the synthesis of a water compatible molecularly imprinted polymer as artificial receptor for detection of 3-nitro-L-tyrosine in neurological diseases, Biosens. Bioelectron. 40 (2013) 336-341.

[66] T. Delatour, F. Fenaille, V. Parisod, J. Richoz, J. Vuichoud, P. Mottier, T. Buetler, A comparative study of proteolysis methods for the measurement of 3 nitrotyrosine residues: enzymatic digestion versus hydrochloric acidmediated hydrolysis, J. Chromatogr. B Anal. Technol. Biomed. Life Sci. 851 (2007) 268-276.

[67] S.D. Gan, K.R. Patel, Enzyme immunoassay and enzyme-linked immunosorbent assay, J. Investig. Dermatol. 133 (2013) e12.

[68] H. Jin, R.C. Zangar, High-throughput, multiplexed analysis of 3-nitrotyrosine in individual proteins, Current Protocols, In Toxicology/Editorial Board, Mahin D. Maines (Editor-In-Chief), [Et Al.], Chapter 17, (2012). 17.15-17.15.

[69] D. Weber, N. Kneschke, S. Grimm, I. Bergheim, N. Breusing, T. Grune, Rapid and sensitive determination of protein-nitrotyrosine by ELISA: application to human plasma, Free Radic. Res. 46 (2012) 276-285.

[70] A.M. Fitzpatrick, L.A.S. Brown, F. Holguin, W.G. Teague, Levels of nitric oxide oxidation products are increased in the epithelial lining fluid of children with persistent asthma, J. Allergy Clin. Immunol. 124 (2009), 990-996.e991-999.

[71] A. Dietrich-Muszalska, J. Malinowska, B. Olas, R. Głowacki, E. Bald, B. Wachowicz, J. Rabe-Jabłońska, The oxidative stress may be induced by the elevated homocysteine in schizophrenic patients, Neurochem. Res. 37 (2012) 1057-1062.

[72] J. Khan, D.M. Brennand, N. Bradley, B. Gao, R. Bruckdorfer, M. Jacobs, $3-$ Nitrotyrosine in the proteins of human plasma determined by an ELISA method, Biochem. J. (Pt 2) (1998 Mar 1) 795-801.

[73] R.S. Sodum, S.A. Akerkar, E.S. Fiala, Determination of 3-nitrotyrosine by highpressure liquid chromatography with a dual-mode electrochemical detector, Anal. Biochem. 280 (2000) 278-285.

[74] R.L. Wixom, C.W. Gehrke, Chromatography: A Science of Discovery, Wiley, 2011.

[75] M. Naushad, M.R. Khan, Ultra Performance Liquid Chromatography Mass Spectrometry: Evaluation and Applications in Food Analysis, Taylor \& Francis, 2014.

[76] V.R. Meyer, Practical High-performance Liquid Chromatography, Wiley, 2013.

[77] H. Kaur, B. Halliwell, Evidence for nitric oxide-mediated oxidative damage in chronic inflammation. Nitrotyrosine in serum and synovial fluid from rheumatoid patients, FEBS Lett. 350 (1994) 9-12.

[78] Y.H. Hitomi, J. Okuda, H. Nishino, Y. Kambayashi, Y. Hibino, K. Takemoto, T. Takigawa, H. Ohno, N. Taniguchi, K. Ogino, Disposition of protein-bound 3nitrotyrosine in rat plasma analysed by a novel protocol for HPLC-ECD, J. Biochem. 141 (2007) 495-502.

[79] H. Yang, Y. Zhang, U. Pöschl, Quantification of nitrotyrosine in nitrated proteins, Anal. Bioanal. Chem. 397 (2010) 879-886.

[80] C. Herce-Pagliai, S. Kotecha, D.E. Shuker, Analytical methods for 3nitrotyrosine as a marker of exposure to reactive nitrogen species: a review, Nitric Oxide Biol. Chem. Off. J. Nitric Oxide Soc. 2 (1998) 324-336.

[81] M.W. Dong, Modern HPLC for Practicing Scientists, Wiley, 2006.

[82] K. Selzle, C. Ackaert, C.J. Kampf, A.T. Kunert, A. Duschl, G.J. Oostingh, U. Pöschl, Determination of nitration degrees for the birch pollen allergen Bet v 1, Anal. Bioanal. Chem. 405 (2013) 8945-8949.

[83] D. Tsikas, M.W. Duncan, Mass spectrometry and 3-nitrotyrosine: strategies, controversies, and our current perspective, Mass Spectrom. Rev. 33 (2014) $237-276$.

[84] H.-J.C. Chen, W.-L. Chiu, Simultaneous detection and quantification of 3nitrotyrosine and 3-bromotyrosine in human urine by stable isotope dilution liquid chromatography tandem mass spectrometry, Toxicol. Lett. 181 (2008) 31-39.

[85] N. Ishida, T. Hasegawa, K. Mukai, M. Watanabe, H. Nishino, Determination of nitrotyrosine by HPLC-ECD and its application, J. Vet. Med. Sci. Jpn. Soc. Vet. Sci. 64 (2002) 401-404.

[86] Y. Hui, M. Wong S.S. Zhao, J.A. Love, D.M. Ansley, D.D.Y. Chen, A simple and robust LC-MS/MS method for quantification of free 3-nitrotyrosine in human plasma from patients receiving on-pump CABG surgery, Electrophoresis 33 (2012) 697-704.

[87] J.P. Gaut, J. Byun, H.D. Tran, J.W. Heinecke, Artifact-free quantification of free 3-chlorotyrosine, 3-bromotyrosine, and 3-nitrotyrosine in human plasma by electron capture-negative chemical ionization gas chromatography mass spectrometry and liquid chromatography-electrospray ionization tandem mass spectrometry, Anal. Biochem. 300 (2002) 252-259.

[88] P.J. Thornalley, S. Battah, N. Ahmed, N. Karachalias, S. Agalou, R. Babaei-Jadidi, A. Dawnay, Quantitative screening of advanced glycation end products in cellular and extracellular proteins by tandem mass spectrometry, Biochem. J. 375 (2003) 581-592

[89] Y. Kato, N. Dozaki, T. Nakamura, N. Kitamoto, A. Yoshida, M. Naito, M. Kitamura, T. Osawa, Quantification of modified tyrosines in healthy and diabetic human urine using liquid chromatography/tandem mass spectrometry, J. Clin. Biochem. Nutr. 44 (2009) 67-78. 